\title{
Role of starch in the ceramic powder synthesis: a review
}

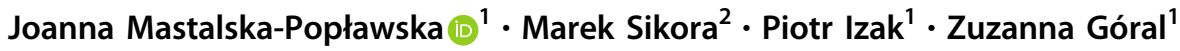

Received: 4 June 2020 / Accepted: 24 August 2020 / Published online: 10 September 2020

(c) The Author(s) 2020

\begin{abstract}
The main goal of this work was to demonstrate a broad range of starch applications in ceramic powder synthesis, and to point out that starch and its derivatives can successfully replace polyvinyl derivatives commonly used in ceramic formulations, as they are water-soluble saccharides, burn out more easily, reduce the exothermicity of the combustion reaction, and allow to receive fine and uniform ceramic powders. Starch is an eco-friendly and easily transformable natural carbohydrate polymer that is found in a variety of applications in ceramics and materials science. In this paper, we review the influence of starch on the physicochemical properties of the ceramic powders obtained by means of various synthesis methods (sol-gel method, combustion process, combined methods, and hydrothermal synthesis). Starch plays a differentiated role in each of these methods, i.e., it is a polymerizing agent in sol-gel method, a fuel in combustion process, and a substrate for carbon spheres in hydrothermal synthesis.
\end{abstract}

\section{Graphical Abstract}

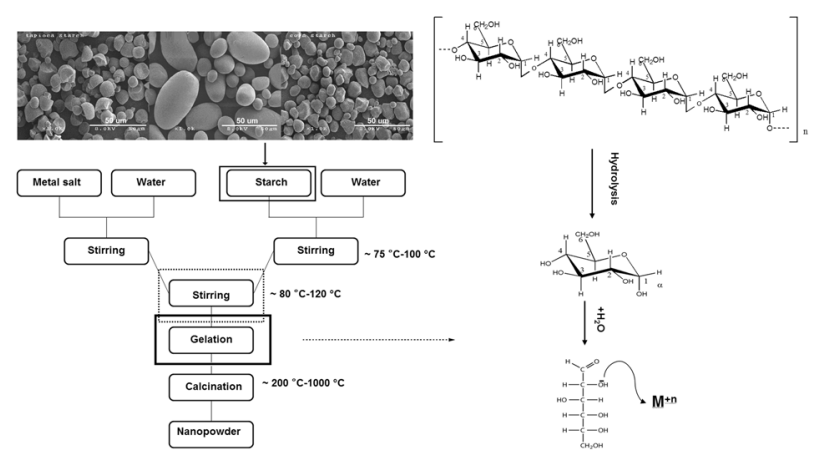

Keywords Starch $\cdot$ Sol-gel synthesis $\cdot$ Combustion process $\cdot$ Sol-gel combustion process $\cdot$ Fuel/oxidation ratio

\section{Highlights}

- Starch can replace polyvinyl derivatives used in ceramic formulations.

- Starch helps to control particle size of the powders and prevents agglomeration.

- Starch helps to create a more compact and porous structure in the sol-gel method.

- Starch is a highly energetic fuel that provides energy during combustion.

Joanna Mastalska-Popławska

jmast@agh.edu.pl

1 AGH University of Science and Technology, Faculty of Materials

Science and Ceramics, al. Mickiewicza 30, 30-059

Krakow, Poland
2 University of Agriculture, Faculty of Food Technology, ul. Balicka 122, 30-149 Krakow, Poland 


\section{Introduction}

The properties of the ceramic products, therein ceramic powders, are largely affected by the phase and morphological characteristics of the initial raw material powders, such as the level of aggregation, purity, particle shape, and uniformity in chemical and phase composition. Another factor is the method of the powder preparation/synthesis, which is divided into three categories, i.e., solid-phase reactant, liquid-phase reactant, and gas-phase reactant. These groups of methods are used mainly for the preparation of ceramic powders that can be subjected to sintering. The last one factor concerns the physicochemical properties of the supporting substances and their role in the preparation/synthesis process. In this case, we can mention carbon (e.g., graphite or carbon black), organic polymers (e.g., polyethylene or polyacrylic acids), or natural biopolymers (e.g., wood flour or starch). Among them, the broadest range of applications shows starch [1,2].

Instead of using nonrenewable, environmentally hazardous, and costly petrochemical-derived additives, which are difficult to treat from the point of view of recycling, starch and its derivatives can offer the ceramic industry a set of applications, multifunctionality, differentiated properties, aqueous processing, and easy burnout. It is worth to point out that starch belongs to the so-called renewable biological resources. Its scope of production fluctuates under the influence of various factors (economy and climate), yet it can be raised considerably in a relatively short period of time [3]. What is more important, products of starch (polysaccharides) pyrolysis are comparable to those of polyvinyl derivatives, commonly used in ceramic formulations, and in comparison to them, water-soluble saccharides burn out more easily and cleaner. Starch can act as the polymerizing, chelating, or gelling agent in sol-gel methods. It can be a substrate for carbon spheres in hydrothermal synthesis, as well as pore-forming agent in the manufacturing of porous ceramic and bioceramic powders. Apart from that, it is an excellent source of carbon and can provide energy in the combustion synthesis process. It should also be mentioned that starch and its derivatives can be applied as binders, rheology modifiers, or even strengthening agents in traditional ceramics manufacturing [4-7].

From the chemical point of view, starch is a carbohydrate polymer consisting of glucose units connected by $\alpha$-glycosidic bonds. It constitutes the main food-reserve material of a majority of higher plants. The most abundant plants capable of synthesizing starch are cereals (corn, wheat, rice, barley, oats, rye, and sorghum), tubers (potato, tapioca, and arrowroot), palm trees (e.g., sago), as well as leguminous plants (e.g., peas) [8]. It occurs in the form of small granules of $2-150 \mu \mathrm{m}$ that are insoluble in water (because of the highly ordered and densely packed glucan chains that create its microstructure). It is also worth to mention that plant origins strongly influence the physicochemical properties of starch, such as structure, shape, size, gelling, and swelling ability (Fig. 1) [9, 10].

Starch processing begins with mechanical removing of its granules from the plant material. It involves processes like grinding, sieving, washing, and filtration. The next step is the physical, chemical, or biological treatment that causes starch transformation into modified derivatives with new properties like, e.g., water solubility. For example, acid hydrolysis breaks long polymer starch chains into shorter ones, as follows: amylodextrin, erythrodextrin, achrodextrin, maltose, and glucose. In turn, heating in the acid environment results in dextrins or so-called British gums that are water soluble [11-17].

This review aims at realization of the great importance of starch in the preparation of ceramic materials, therein ceramic powders. In our previous work [18], we have described use of starch and its derivatives in different sections of ceramics, starting with traditional ceramics and ending with bioceramics. From that time, because inter alia of its eco-friendly properties, starch found a lot more interest in described areas, especially ceramic powder preparation. For this reason, because some older patents and articles could lose their topicality, it seemed reasonable to resume this topic again, and this review is based only on articles about ceramic powder synthesis written after 2005 . We have focused on the role and importance of starch in

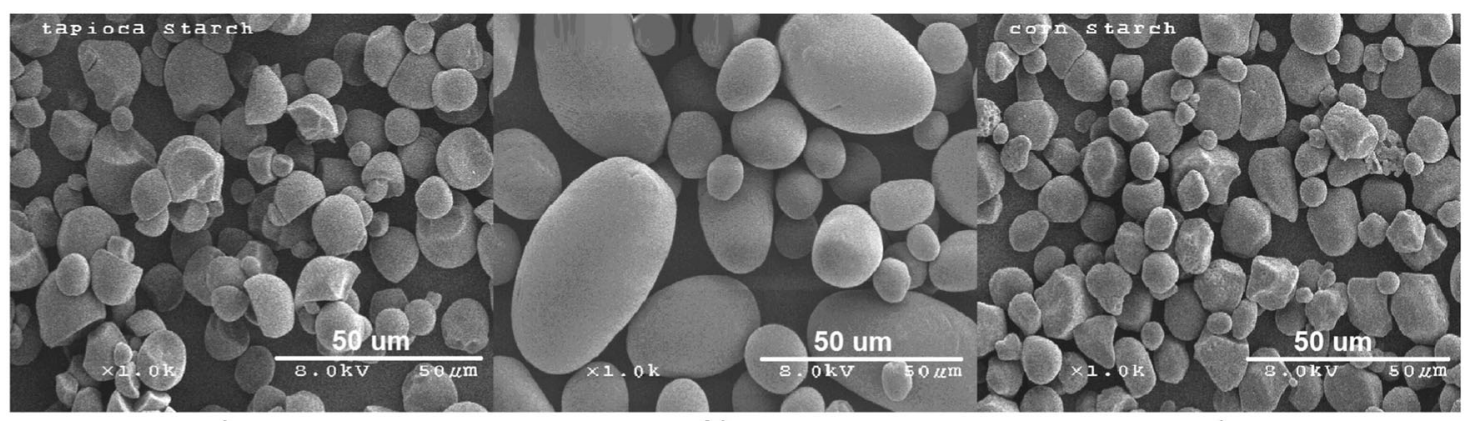

a) b) c)

Fig. 1 SEM images of a tapioca, b potato, and c corn starch granules (magnification $\times 1000)$ [18] 
terms of its applications in methods leading to the production of ceramic powders. Starch is an eco-friendly and easily transformable carbohydrate polymer that plays a differentiated role in the ceramic powder synthesis.

\section{Role of starch in different methods of ceramic powder synthesis}

\subsection{Sol-gel method}

Sol-gel process is a method of the production of inter alia ceramic powders. It consists in the slow dehydration of the hydroxide sol of a given powder, resulting in a gel, which then undergoes the calcination process and turns into fine and uniform powder. The advantage of this method is the relatively low production cost and the possibility of obtaining various types of materials. On the other hand, the disadvantages include the difficulties associated with the controlling of the particle size and the degree of its agglomeration. This problem can be minimized by applying either various capping agents that block the growth of grains or polymerizing agents that support gelling process of the system. Currently, the most commonly used for this purpose are polymers of natural origin, mainly starch and its derivatives (Fig. 2) [19-30].
Zak et al. [19] used the sol-gel method with the presence of starch as the stabilizer to control the cation mobility and growth of the resulting $\mathrm{ZnO}$ nanoparticles. According to the increasing calcination temperatures $\left(400-600^{\circ} \mathrm{C}\right), \mathrm{ZnO}$ nanopowders of $28-51 \mathrm{~nm}$ and of hexagonal structure were obtained. Balcha et al. [20] obtained similar results. Using a calcination temperature of $600{ }^{\circ} \mathrm{C}$, they got crystallites with a size of $28 \mathrm{~nm}$ and of hexagonal wurtzite structure. They also proved that the sol-gel method is better than precipitation, because the obtained crystallites are smaller and their photocatalytic properties are better. In turn, de Almeida et al. [21] received $\mathrm{ZnO}$ crystallites of $20 \mathrm{~nm}$, using the calcination temperature of $500{ }^{\circ} \mathrm{C}$ by $2 \mathrm{~h}$. They also concluded that the cassava starch used as the stabilizing agent inhibits the crystal growth, thanks to the interaction of the $\mathrm{C}-\mathrm{O}$ groups of the glucose (resulted from the starch hydrolysis) and zinc cations.

Darroudi et al. [22] produced crystalline nanoceria powders by the sol-gel method in an aqueous solution. Long-chained starch terminated the growth of nanoceria particles during the reaction and stabilized them by covering the powder nanoparticles with hydroxyl groups as a capping agent. The resulting cerium hydroxide samples were further calcined in the temperature range $200-600{ }^{\circ} \mathrm{C}$ for $2 \mathrm{~h}$ to obtain $\mathrm{CeO}_{2}$ nanopowders of about $6 \mathrm{~nm}$ with a cubic

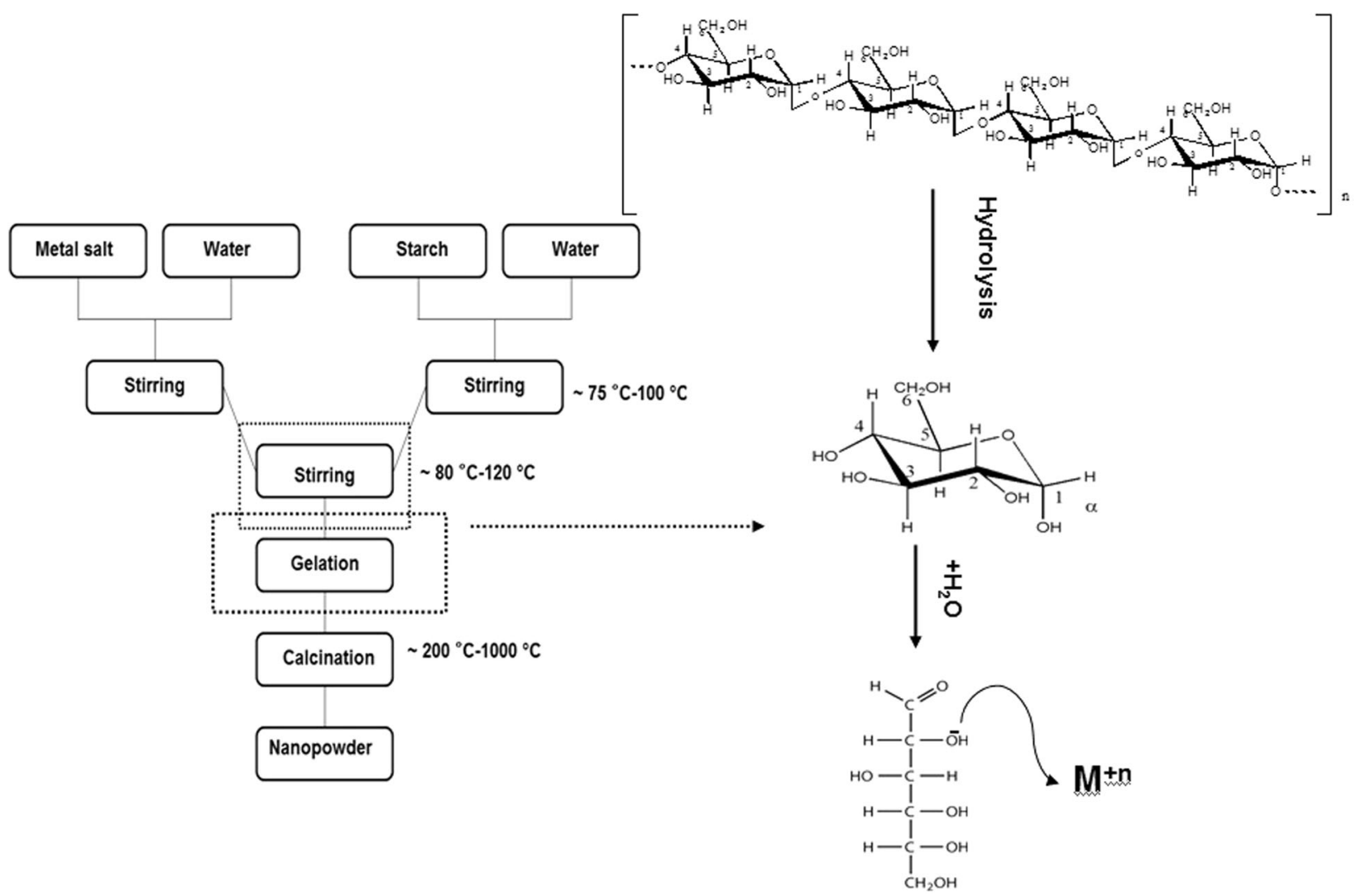

Fig. 2 Scheme of the starch-doped sol-gel preparation of the ceramic nanopowders 
Table 1 Characterization of ceramic nanopowders obtained by sol-gel methods

\begin{tabular}{lllll}
\hline $\begin{array}{l}\text { Synthesized } \\
\text { powder }\end{array}$ & Role of starch & $\begin{array}{l}\text { Temperature of } \\
\left.\text { calcination [ }{ }^{\circ} \mathrm{C}\right]\end{array}$ & $\begin{array}{l}\text { Crystallite } \\
\text { size [nm] }\end{array}$ & References \\
\hline $\mathrm{ZnO}$ & Stabilizer & $400-600$ & $20-51$ & [19], [20], [21] \\
$\mathrm{CeO}_{2}$ & Capping (chelating) agent/stabilizer & $200-600$ & $6-16$ & [22], [23] \\
$\mathrm{CuO}$ & Stabilizer & 400 & 54 & {$[24]$} \\
$\mathrm{TiO}_{2}$ & Stabilizer & 500 & $28-40$ & {$[25]$} \\
$\mathrm{Al}_{2} \mathrm{O}_{3}$ & Capping agent/stabilizer & $350-1200$ & $3-20$ & {$[26]$} \\
$\mathrm{BaCeO}_{3}$ & Polymerizing agent & 920 & 41 & {$[27]$} \\
$\mathrm{LaFeO}_{3}$ & Polymerizing/complexing agent & $570-1000$ & $37-130$ & {$[28],[29]$} \\
$\mathrm{PbTiO}_{3}$ & Capping agent & 700 & $30-50$ & {$[30]$} \\
\hline
\end{tabular}

fluoride structure. Ferreira et al. [23] obtained nanoceria powders of $\sim 8-16 \mathrm{~nm}$ and of fluoride structure using cassava starch as the chelating agent and calcination temperature $200-500{ }^{\circ} \mathrm{C}$ for $1 \mathrm{~h}$.

Alishah et al. [24] investigated the antimicrobial properties of the copper oxide nanopowders produced via the starch-assisted sol-gel method. The temperature of the gel formation in this process was $65^{\circ} \mathrm{C}$, whereas calcination temperature was $400{ }^{\circ} \mathrm{C}$. The utilized carbohydrate helped to received stable and spherical-shaped nanopowders, whose average size was $54 \mathrm{~nm}$.

Khodadadin [25] compared the structural, optical, and photocatalytic properties of the undoped and $\mathrm{Nd}-\mathrm{Ce}$ codoped titanium dioxide, where starch was used as the "green" modifier that prevents agglomeration, limits excessive grain growth, and in conclusion modifies the photocatalytic activity of the synthesized nanopowders. He also revealed that small amounts of dopants (up to $1 \mathrm{~mol} \%$ ) improve the photocatalytic activity because they reduce the bandgap. Higher dopant amount ( 2 mol\%) means occupation of the active surface sites by the $\mathrm{Ce}$ and $\mathrm{Nd}$ particles, and as a result, disturbs the photocatalytic effect.

Zhang et al. [26] compared the capping/stabilizing properties of acrylamide and starch/glutaric dialdehyde in sol-gel synthesis of alumina nanopowders. Both of the mentioned systems helped to form a matrix (without any inititators and cross-linking agents, just self-polymerization in temperature of about $100{ }^{\circ} \mathrm{C}$ ) for the entrapped metal ions and gave rise to alumina particles during heating. In both cases, the formed gel was dried for $36 \mathrm{~h}$ at a temperature of about $95{ }^{\circ} \mathrm{C}$ and then calcined at various temperatures from 350 to $1200{ }^{\circ} \mathrm{C}$. The difference was in the heating temperatures in which alumina phases started to occur. For acrylamide, a $\mathrm{g}-\mathrm{Al}_{2} \mathrm{O}_{3}$ phase began to appear already at a temperature of $650{ }^{\circ} \mathrm{C}$, whereas for the starch/glutaric dialdehyde it was $804{ }^{\circ} \mathrm{C}$. The phase system from $\mathrm{g}$ to a started at $1100{ }^{\circ} \mathrm{C}$ for both systems, and a pure a- $\mathrm{Al}_{2} \mathrm{O}_{3}$ phase appeared at $1200{ }^{\circ} \mathrm{C}$. What speaks more for the starch/ glutaric aldehyde system is that in this configuration, this monomer is less toxic than acrylamide itself.

Koferstein et al. [27] synthesized $\mathrm{BaCeO}_{3}$ nanopowder in the sol-gel reaction with the use of starch as a polymerizing agent. The obtained (BaCe) gel, after heating up to $920{ }^{\circ} \mathrm{C}$, transformed to pure $\mathrm{BaCeO}_{3}$, which was characterized by a specific surface area of $15.4 \mathrm{~m}^{2} / \mathrm{g}$ and a crystallite size of about $41 \mathrm{~nm}$. This method was also used to obtain $\mathrm{LaFeO}_{3}$ nanopowders exhibiting improved magnetic and optical properties [28, 29]. Calcination of $(\mathrm{LaFe})$ gel at $570{ }^{\circ} \mathrm{C}$ allowed to obtain the pure phase of $\mathrm{LaFeO}_{3}$ powder with a specific surface area of $25.7 \mathrm{~m}^{2} / \mathrm{g}$ and a crystal size of $37 \mathrm{~nm}$, while increasing the temperature to $100{ }^{\circ} \mathrm{C}$, Tizro and Kamali [30] used the sol-gel method to obtain $\mathrm{PbTiO}_{3}$ nanoparticles subsidized with silver. In addition to starch, glucose and lactose were used as the gelling agents. Analyzing scanning electron microscope (SEM) images, it was found that in the case of glucose, $\mathrm{PbTiO}_{3}$ powder was compacted into micrometric-size agglomerates. Using lactose, the number of agglomerates was reduced, and nanoparticles in the range of $200-400 \mathrm{~nm}$ were obtained, whereas in the case of starch, spherical particles with grain sizes of 30-50 nm were obtained.

Starch, thanks to its structure, i.e., long polymer chains, single-helix structure, and a-glucose units, covers the surface of nanograins by hydroxyl groups, becoming the capping agent and matrix for the nascent powders, preventing their excessive growth. In addition, thanks to the presence of a large number of hydroxyl groups that have the same properties as those coming from alcohols, starch can be used as the oxidation agent for metal salts, i.e., it is a good polymerization agent (Table 1).

\subsection{Combustion process}

Combustion synthesis, i.e., self-propagating high-temperature synthesis, is one of the most efficient and economic way of obtaining ceramic powders, due to its simple 
experimental route, relatively fast procedure, and what is the most important, high-purity products. This method introduces high reaction temperature and specific heating/ cooling rate, which helps to control the microstructure of the powders. In typical combustion synthesis, the first step involves the reaction between an oxidant precursor (usually metal nitrate) and a fuel (organic derivative) that is a reagent reducer. Energy produced as a result of the reaction sustains a further process, resulting in the ignition of reagents and the formation of a ceramic powder. The resultant products are metal oxide or its spinel, carbon dioxide, water vapor, and nitrogen. The crucial parameters here are the type of the combustion fuel and fuel-to-oxidation ratio. Selecting the fuel, we should remember about its enthalpy of combustion. The lower this parameter is, the lower the exothermicity of the combustion process, and the lower the temperature at which the selected powder is synthesized. In the past, hydrazide-type compounds have been used, but nowadays, because of its nontoxicity, mainly urea, carbon, and polysaccharides are used, among which the most popular is starch. For example, combustion enthalpy of urea $\left(\mathrm{DH}_{\mathrm{f}}\right)$ is $-147.26 \mathrm{kcal} / \mathrm{mol}$, whereas that for starch is $-401.57 \mathrm{kcal} /$ mol. Considering the ratio of fuel to the oxidant, three cases are possible. Stoichiometric (described above), fuel lean, in which oxygen is in excess and it appears in exhaust gas, and fuel rich, in which oxygen is deficient, so a portion of atmospheric oxygen is necessary to complete the reaction [31-33].

Tahmasebi and Paydar [32] studied the effect of starch addition on the solution combustion synthesis of $\mathrm{Al}_{2} \mathrm{O}_{3}-\mathrm{ZrO}_{2}$ powder. Because of the large heat of formation of starch molecules, they replaced urea with starch in the mixture of fuels, and in this way, reduced the exothermicity of the combustion reaction. This prevented the sintering of particles and resulted in fine agglomerates of the $\mathrm{Al}_{2} \mathrm{O}_{3}-\mathrm{ZrO}_{2}$ composite powder crystallites with a diameter less than $20 \mathrm{~nm}$.

Qui et al. [34] examined the possibility of the production of AlN powder from combustion synthesis precursors, such as carbon black, glucose, sucrose, citric acid, and watersoluble starch. When the carbon source was carbon black, pure AlN powder was found in the sample calcined at $1500^{\circ} \mathrm{C}$, whereas for the precursors based on water-soluble organics, pure AlN powder was already found in the samples calcined at $1400^{\circ} \mathrm{C}$. Comparing the particle size and shape, it was found that AlN powders synthesized with the use of inter alia starch, had fine spherical shape and particle size of about $100 \mathrm{~nm}$, whereas those based on carbon black were larger and their size distribution was wider.

Bai et al. [35] used the solution combustion synthesis to obtain $\mathrm{MgO}$ powders. The fuel-to-oxidation ratio was the crucial factor and because of that, various redox mixtures with starch-to-magnesium-nitrate mole ratio of 5.5:12, 5:12,
4.5:12, and 4:12 were examined. During the combustion process, nanoporous agglomerates were formed and the average crystalline size was about $8 \mathrm{~nm}$. This value was growing up together with the starch content. They also used [33] the same method to obtain $\mathrm{MgAl}_{2} \mathrm{O}_{4}$ powders. As the fuel for the process, they were testing urea, glycine, and starch in various combinations and ratios. Their tests confirmed the positive effect of starch addition (0-35.6 wt\%) on the specific surface area (from 13.36 to $35.53 \mathrm{~m}^{2} / \mathrm{g}$ ) and crystallite size (from $200 \mathrm{~nm}$ to even $15 \mathrm{~nm}$ ).

Raja et al. [36] compared the processing properties of starch, urea, and glycine in microwave combustion synthesis of $\mathrm{Co}_{3} \mathrm{O}_{4}$ nanopowders. Instead of traditional heating, they used microwave energy (2.45-GHz multimode cavity at $850 \mathrm{~W}$ for $10 \mathrm{~min}$ ). The average crystallite sizes for the starch, urea, and glycine-assisted cobalt oxide nanopowders were 23.3, 26.9, and $30.2 \mathrm{~nm}$, respectively. Another significant difference was in the shape formation of the obtained nanoparticles. Starch-assisted grains were nanorods, whereas urea- and glycine-assisted ones were spherical-like and nanospheres, respectively. In turn, magnetic measurements revealed that if the fuel is starch, cobalt oxide is ferromagnetic, whereas if the fuel is urea or glycine, cobalt oxide is superparamagnetic.

Visinescu et al. [37] used the low-temperature combustion-based synthesis to obtain zinc aluminate oxides. Starch was tested as a single fuel and in a two-fuel mixture with $\mathrm{N}$ methylurea in various ratios. The combustion process started in the temperature range of $170-450^{\circ} \mathrm{C}$, but the pure spinelic phase was obtained at $800^{\circ} \mathrm{C}$. It was proved that the presence of starch helped to lower the temperature and increased the time of combustion reaction, i.e., starch decreased the process exothermicity. Starch-derived zinc aluminate oxides were in the form of porous aggregates in contrast to N-methylurea-based denser forms.

To obtain $\mathrm{BiFeO}_{3}$, Koferstein [38] used a combustion method supported by starch that served as a complexing agent. (BiFe) gel was calcined at a temperature range of $500-750{ }^{\circ} \mathrm{C}$, and pure-phase $\mathrm{BiFeO}_{3}$ powder was obtained already at $550{ }^{\circ} \mathrm{C}$. Further increase in temperature caused gradual grain degradation to $\mathrm{Bi}_{25} \mathrm{FeO}_{40}$ and $\mathrm{Bi}_{2} \mathrm{Fe}_{4} \mathrm{O}_{9}$. This process was also dependent on the degree of heating and the fuel/oxidizer ratio.

Khattab et al. [39] used a modified combustion method to obtain $\mathrm{Co}_{x} \mathrm{Mg}_{1-x} \mathrm{Al}_{2} \mathrm{O}_{4}$ blue pigments. The output powders were prepared as a result of the microwave combustion method. Then, to optimize the spinel formation, the resulting powder precursors were calcined at 400, 550, and $800^{\circ} \mathrm{C}$. Starch used in this process as a combustion fuel caused the powder precursors to become oxidants. In addition, by analyzing the DTA and TG curves, it was found that the temperature degradation of starch contributed to the reduction in particle size of the powder. 
Table 2 Characterization of ceramic nanopowders obtained by the combustion process

\begin{tabular}{llll}
\hline Synthesized powder & $\begin{array}{l}\text { Temperature of the } \\
\text { calcination }\left[{ }^{\circ} \mathrm{C}\right]\end{array}$ & $\begin{array}{l}\text { Crystallite } \\
\text { size }[\mathrm{nm}]\end{array}$ & References \\
\hline $\mathrm{Al}_{2} \mathrm{O}_{3}-\mathrm{ZrO}_{2}$ & 500 & 20 & {$[32]$} \\
$\mathrm{AlN}$ & 1400 & 100 & {$[34]$} \\
$\mathrm{MgO}$ & 400 & 8 & {$[35]$} \\
$\mathrm{Co}_{3} \mathrm{O}_{4}$ & - & 23 & {$[36]$} \\
$\mathrm{MgAl}_{2} \mathrm{O}_{4}$ & 900 & 17 & {$[33]$} \\
$\mathrm{ZnAl}_{2} \mathrm{O}_{4}$ & 800 & $15-30$ & {$[37]$} \\
$\mathrm{BiFeO}_{3}$ & $500-750$ & $36-243$ & {$[38]$} \\
$\mathrm{Co}_{x} \mathrm{Mg}_{1-x} \mathrm{Al}_{2} \mathrm{O}_{4}$ & $400-800$ & $35-100$ & {$[39]$} \\
\hline
\end{tabular}

The above studies confirmed excellent starch properties as combustion fuel among different organic derivatives such as urea and glycine. The more carbon in the precursor and the lower combustion enthalpy, the better properties of the ceramic powders synthesized by the combustion process can be obtained (Table 2). Due to the fact that starch can provide a lot of energy to the system during combustion, as a result of which the exothermicity of the reaction is reduced, the temperature at which the powder can be synthesized is also lowered. Despite these important advantages, there are a few things to keep in mind that can disturb the starch-assisted combustion process. It should be remembered about the mass ratio of starch to metal nitrate, i.e., fuel-to-oxidation ratio. If it will be lower or higher than the stoichiometric one, we will get impure powder or a fully nonsynthesized one.

\subsection{Combined methods}

Besides combustion method and sol-gel process, ceramic powders can be obtained by the use of other methods, mainly combined ones. Starch here plays a role of the capping agent and/or carbon source. For example, thanks to the combination of the sol-gel process and combustion synthesis, fine ceramic powders, mainly spinels, with high homogeneity and purity, can be obtained. The biggest group of the powders that can be obtained via the starch-assisted sol-gel combustion method are ferrites.

The starch-assisted sol-gel combustion method was used by Koferstein et al. [40] to obtain $\mathrm{MgFe}_{2} \mathrm{O}_{4}$, which was then subjected to isothermal sintering in the temperature range of $550-1100^{\circ} \mathrm{C}$ for 1 or $10 \mathrm{~h}$. The resulting sintered materials exhibited varying magnetic properties, depending on the particle size, which could be adjusted using starch. Yadav et al. [41] synthesized $\mathrm{NiFe}_{2} \mathrm{O}_{4}$ nanoparticles by the use of this method, where starch acted as the source of organic fuel. Gel obtained from the sol-gel process was heated up to $200{ }^{\circ} \mathrm{C}$ to initiate a self-sustaining combustion reaction.
Such obtained powders were annealed in air atmosphere at $200-1000^{\circ} \mathrm{C}$. X-ray powder diffraction (XRD) analysis showed the improvement of crystallinity with the increment of annealing temperature. Also, the higher was the temperature, the bigger size of particles was observed, starting from 5 to $15 \mathrm{~nm}$ at $200{ }^{\circ} \mathrm{C}$ (spherical shape), up to $70-300 \mathrm{~nm}$ at $1000{ }^{\circ} \mathrm{C}$ (spherical and elongated shape). It was also proved that better crystallinity can be achieved by a proper ratio of starch and nitrate. They have used the same method to synthesize $\mathrm{Co}_{1-x} \mathrm{Zn}_{x} \mathrm{Fe}_{2} \mathrm{O}_{4}$ spinel ferrite nanoparticles [42], $\mathrm{Nd}^{3+}$-doped $\mathrm{CoFe}_{2} \mathrm{O}_{4}$ spinel ferrite nanoparticles [43], and $\mathrm{ZnFe}_{2} \mathrm{O}_{4}$ spinel ferrite nanoparticles [44].

Dinh et al. [45] studied the effect of annealing temperatures $\left(700,800\right.$, and $\left.900{ }^{\circ} \mathrm{C}\right)$ and $\mathrm{Cu}^{2+} / \mathrm{Fe}^{3} /$ starch ratio on the magnetic and catalytic properties of $\mathrm{CuFe}_{2} \mathrm{O}_{4}$ powders. The higher the annealing temperature was, the more tetragonal spinel structure phase was observed and the less impurity phases like $\mathrm{CuO}$ were observed. Increasing the starch content in the examined systems, it was found that it does not affect the morphology of samples, but the particle size (from 100 to even $500 \mathrm{~nm}$ ) and the photocatalytic activity. The optimal annealing temperature was $800{ }^{\circ} \mathrm{C}$ and the optimal $\mathrm{Cu}^{2+} / \mathrm{Fe}^{3+} /$ starch ratio was 1:2:3.

Ansari et al. [46] received $\mathrm{CoTiO}_{3} / \mathrm{CoFe}_{2} \mathrm{O}_{4}$ nanopowders with enhanced magnetic and electrochemical properties via the sol-gel autocombustion method. They compared fuel, capping, and the reducing properties of glucose, maltose, and starch. The effect of added sugars, Tito-Co ratio, and calcination temperature was also studied. Gelation and autocombustion temperatures were $60^{\circ} \mathrm{C}$ and $120^{\circ} \mathrm{C}$, respectively, whereas the calcination process was carried out at two temperatures $\left(650\right.$ and $\left.7500^{\circ} \mathrm{C}\right)$ and lasted for $1 \mathrm{~h}$. It was proved that the more complex sugar used in the synthesis as a reducing agent, the better-formed powder grains can be obtained. Using glucose, a highly agglomerated product was obtained, whereas for maltose and starch aggregates, spherical nanoparticles were obtained. They also confirmed the fact that the more hydroxyl groups are in sugar, the better the powder grains are covered with carbohydrate and no large agglomerates are formed, and in the later stages, spherical powder particles are formed as a result of the combustion process. It is also easier to control the size of nanoparticles. When the calcination temperature was lower (more fuel in the system), the reaction rate also slowed down (particles had more time to react), which resulted in a more regular grain shape. It was also found that by reducing the amount of starch in the system, the grain size and degree of agglomeration increase.

Smirnova et al. [47] used a mixture of glycine and starch to synthesize $\mathrm{Mg}\left(\mathrm{Fe}_{0.8} \mathrm{Ga}_{0.2}\right)_{2} \mathrm{O}_{4}$ spinel nanopowders. The use of glycine alone causes contamination of the powder by dimensional inhomogeneity of particles and larger crystallites are formed $(50-100 \mathrm{~nm})$, whereas for the mass ratio of 
glycine to starch 8:1, pure $\mathrm{Mg}\left(\mathrm{Fe}_{0.8} \mathrm{Ga}_{0.2}\right)_{2} \mathrm{O}_{4}$ crystallites of $40-50 \mathrm{~nm}$ are formed.

In turn, Agilandeswari and Kumar [48], using starchassisted sol-gel combustion method, obtained $\mathrm{Ca}_{3} \mathrm{Co}_{4} \mathrm{O}_{9}$ powder with improved magnetic and electrical properties. As a sol-gel mixture, solution containing cobalt and calcium nitrates, and starch was used. By heating such a mixture to $120^{\circ} \mathrm{C}$, a gel, which after further thermal treatment converted into a noncarbonate $\mathrm{Ca}_{3} \mathrm{Co}_{4} \mathrm{O}_{9}$ phase, was obtained. On the basis of TG/DTA analysis, it was found that the starch presence contributed to a significant reduction in the reaction exothermicity, i.e., the exothermic oxidation of carbon generated a thermal reaction that allowed the conversion of cobalt oxide and calcium carbonate into calcium cobaltite.

Freitas et al. [49] compared four complexing agents: citric acid, glycine, corn starch, and gelatin in sol-gel autocombustion synthesis of $\mathrm{LiCoO}_{2}$ nanopowders. SEM and XRD research has shown the rhombohedral phase in all samples and a small amount of cubic $\mathrm{Co}_{3} \mathrm{O}_{4}$ spinel in the samples with starch and gelatin, as well as in the blank test (without any gelation additive). Gelation temperature of each sample varied between 70 and $80^{\circ} \mathrm{C}$, but the significant dissimilarity was in the gelation time. The longest time was for the samples based on citric acid $(5 \mathrm{~h})$, next gelatin and glycine $(3 \mathrm{~h})$, and the shortest time was for the samples based on starch $(1 \mathrm{~h})$. Combustion temperature was $300^{\circ} \mathrm{C}$ and calcination temperature was $700^{\circ} \mathrm{C}$. Based on the XRD data, the calculated average size of $\mathrm{LiCoO}_{2}$ crystallites was as follows: $66-70 \mathrm{~nm}$ for glycine, $69-72 \mathrm{~nm}$ for citric acid, $70-75 \mathrm{~nm}$ for starch, and $73-75 \mathrm{~nm}$ for gelatin. The larger size of crystallites is related to the fuel type, because decomposition of starch and gelatin gives more energy to the system during the formation of nanocrystallites.

Motevalian and Salem [50] investigated the influence of glycine-potato starch mixing ratio on the structural properties of $\mathrm{MgAl}_{2} \mathrm{O}_{4}$ nanopowders synthesized with the use of sol-gel autocombustion method. Both additives are complexing agents as well as fuel additives. But starch changes ignition from flame to smoldering and because of that, it lowers the temperature of the autoignition process. Addition of starch counteracts agglomeration and facilitates the reaction between solid-phase and gas species, resulting in more pure spinel powder (purity increased after $10 \mathrm{wt} \%$ addition of starch).

Ramasami et al. [51] obtained photocatalytically and antimicrobially active $\mathrm{ZnO}$ powders via the sol-gel autocombustion process. As the carbohydrate additive, they have used tapioca starch pearls that they mixed with zinc nitrate hexahydrate in the mass ratio of nitrate:starch $1: 1$, 1:0.5, and 1:0.25. The best ratio was the middle one.
Thanks to it, spherical nanoparticles of $45 \mathrm{~nm}$ were obtained.

Starch can also be a source of carbon in the synthesis of ceramic powders. Okano and Suzuki [52] developed a hydrothermal synthesis of carbonate spheres (CSs) using corn, potato, and rice starch. After hydrothermal treatment of aqueous starch suspensions at $160^{\circ} \mathrm{C}$ for $4-16 \mathrm{~h}$, followed by washing and drying, CSs were obtained. Chemically, these spheres did not differ from each other. As an effect of increasing starting mass and hydrothermal treatment time, larger particles were obtained. In the case of potato starch, probably due to its type $B$ structure, the narrowest particles were obtained. This confirms the assumption that the initial crystalline structure of the starch interacts with hydrothermal reactions.

Wei et al. [53] obtained chromium oxide green pigment during the hydrothermal reaction in an autoclave $\left(200{ }^{\circ} \mathrm{C}\right.$, $2.5 \mathrm{~h}$ ) between $\mathrm{Na}_{2} \mathrm{CrO}_{4}$ and starch, and further calcination of amorphous $\mathrm{Cr}(\mathrm{OH})_{3}\left(950^{\circ} \mathrm{C}, 2 \mathrm{~h}\right)$. The mineralizer effect (carbonates and urea) on the synthesis conditions of the pigment was also studied. The results indicate that conversion of chromate was promoted by the type of mineralizer and its content. The best results ( $98.9 \%$ of conversion) were obtained in the presence of $\mathrm{NaHCO}_{3}$ at $10-100 \mathrm{~g} / \mathrm{L}$, and when the temperature of the reaction was higher than $100^{\circ} \mathrm{C}$.

In turn, Yang et al. [54], in the single-stage carbonationreduction process, where soluble starch served as a carbon carrier, received WC-Co composite nanopowders with spherical shape and average particle size in the range of 43-339 nm.

Visinescu et al. [55] obtained nanograins of $\mathrm{Co}_{x} \mathrm{Zn}_{1-x} \mathrm{Al}_{2} \mathrm{O}_{4}$ ( $x=0.1,0.2,0.4,0.6,0.8$, and 1$)$ blue pigment, using starch gelation process. In the first step, an aqueous solution containing starch and $\mathrm{Zn}$ (II), Co (II), and $\mathrm{Al}$ (III) salts was heated to $80^{\circ} \mathrm{C}$ to obtain a gel. Then, the material was subjected to heat treatment at $800^{\circ} \mathrm{C}$ to obtain a gel with high homogeneity of metallic precursors, which lowered the temperature required to spinel crystallization (from 713 to $684^{\circ} \mathrm{C}$ ).

As one can see, in combined methods, thanks to a synergy effect, starch allows to obtain ceramic powders with better properties and to lower the process temperature. Almost all types of ceramic powders (Table 3) can be obtained using combined methods, in particular, ferrites and spinels. In favor of starch is the fact that it gels faster than other organic agents. Due to the presence of a large number of hydroxyl groups in its structure, it is able to "stick" more and tightly to the grains of the resulting powder, thanks to which a desirable shape of particles, generally spherical, with a low degree of agglomeration, is obtained. By controlling its quantity, grain size of the ceramic powders can also be controlled. However, it is important to choose a 
Table 3 Characterization of ceramic nanopowders obtained by starch-assisted combined methods

\begin{tabular}{|c|c|c|c|c|}
\hline Synthesized powder & Type of process & $\begin{array}{l}\text { Temperature of the } \\
\text { calcination }\left[{ }^{\circ} \mathrm{C}\right]\end{array}$ & $\begin{array}{l}\text { Crystallite } \\
\text { size }[\mathrm{nm}]\end{array}$ & References \\
\hline $\mathrm{MgFe}_{2} \mathrm{O}_{4}$ & \multirow{12}{*}{$\begin{array}{l}\text { Sol-gel autocombustion } \\
\text { synthesis }\end{array}$} & $550-1100$ & $7-15$ & {$[40]$} \\
\hline $\mathrm{NiFe}_{2} \mathrm{O}_{4}$ & & $200-1000$ & $5-300$ & {$[41]$} \\
\hline $\mathrm{Co}_{1-x} \mathrm{Zn}_{x} \mathrm{Fe}_{2} \mathrm{O}_{4}$ & & 800 & $\sim 19-40$ & {$[42]$} \\
\hline $\mathrm{Nd}^{3+}$-doped $\mathrm{CoFe}_{2} \mathrm{O}_{4}$ & & 700 & $\sim 4-20$ & [43] \\
\hline $\mathrm{ZnFe}_{2} \mathrm{O}_{4}$ & & $400-800$ & $5-70$ & [44] \\
\hline $\mathrm{CuFe}_{2} \mathrm{O}_{4}$ & & $700-900$ & $100-500$ & {$[45]$} \\
\hline $\mathrm{CoTiO}_{3} / \mathrm{CoFe}_{2} \mathrm{O}_{4}$ & & $650-750$ & $20-50$ & [46] \\
\hline $\mathrm{Mg}\left(\mathrm{Fe}_{0.8} \mathrm{Ga}_{0.2}\right)_{2} \mathrm{O}_{4}$ & & 700 & $40-50$ & {$[47]$} \\
\hline $\mathrm{Ca}_{3} \mathrm{Co}_{4} \mathrm{O}_{9}$ & & 700 & $150-300$ & {$[48]$} \\
\hline $\mathrm{LiCoO}_{2}$ & & 700 & $70-75$ & [49] \\
\hline $\mathrm{MgAl}_{2} \mathrm{O}_{4}$ & & 900 & $12.5-19$ & {$[50]$} \\
\hline $\mathrm{ZnO}$ & & 500 & 45 & {$[51]$} \\
\hline Carbonate spheres & \multirow[t]{2}{*}{ Hydrothermal synthesis } & 160 & $0.22-7.20 \mu \mathrm{m}$ & {$[52]$} \\
\hline $\mathrm{Cr}_{2} \mathrm{O}_{3}$ & & 950 & - & {$[53]$} \\
\hline WC-Co & $\begin{array}{l}\text { Single-stage carbonation- } \\
\text { reduction process }\end{array}$ & 1100 & 43-339 & {$[54]$} \\
\hline $\mathrm{Co}_{x} \mathrm{Zn}_{1-x} \mathrm{Al}_{2} \mathrm{O}_{4}$ & Starch gelation process & 800 & $\sim 27$ & {$[55]$} \\
\hline
\end{tabular}

proper fuel-to-oxidation ratio and not to overdo the starch content because we will get an impure final powder product.

\section{Conclusions}

The properties of ceramic powders largely affect the final properties of ceramic materials. The most important factors include high purity, the ability to control particle shape, homogeneity in chemical composition and phase, lack of aggregation, and narrow size range. Three groups of methods are used for the preparation of ceramic powders that are subjected to sintering: solid-phase synthesis, liquidphase synthesis, and gas-phase synthesis. In this case, starch can act as a chelating and gelling agent (sol-gel method) or providing energy in the combustion synthesis process. Based on the shown examples, it can also be concluded that the use of starch allows to lower the temperature of the ceramic powder formation. We have proved that starch is an eco-friendly and easily transformable carbohydrate polymer that plays a differentiated role in the ceramic powder synthesis.

In the case of the sol-gel method, when the gel network is formed, starch helps to create a more compact and porous structure. Thanks to this, the resulting particles hang in space and do not agglomerate, and in the drying stage, when shrinkage and densification occur, more solvent is removed from the system. Despite the obvious advantages of the starch-assisted sol-gel process, only oxides and their mixtures can be synthesized using this method. In turn, considering the benefits of starch-assisted combustion method, the most important of them is the fact that starch is a highly energetic fuel that provides energy during combustion, and as a result, lowers the calcination temperature. Using this starch-assisted method, more types of ceramic powders, such as nitrates and spinels, in which synthesis requires a higher temperature, can be obtained. Among the combined methods, starch-assisted sol-gel combustion is the leader. A combination of the sol-gel process and combustion allows for even more accurate crystallite-size control. Thanks to this method, most types of ceramic powders can be synthesized, among which ferrites, mainly used for the production of magnetic materials, lead.

\section{Compliance with ethical standards}

Conflict of interest The authors declare that they have no conflict of interest.

Publisher's note Springer Nature remains neutral with regard to jurisdictional claims in published maps and institutional affiliations.

Open Access This article is licensed under a Creative Commons Attribution 4.0 International License, which permits use, sharing, adaptation, distribution and reproduction in any medium or format, as long as you give appropriate credit to the original author(s) and the source, provide a link to the Creative Commons license, and indicate if changes were made. The images or other third party material in this article are included in the article's Creative Commons license, unless indicated otherwise in a credit line to the material. If material is not included in the article's Creative Commons license and your intended use is not permitted by statutory regulation or exceeds the permitted use, you will need to obtain permission directly from the copyright holder. To view a copy of this license, visit http://creativecommons. org/licenses/by/4.0/. 


\section{References}

1. Gregorova E, Zivcova Z, Pabst W (2009) Starch as a pore-forming and body-forming agent in ceramic technology. Starch 61:495-502

2. Thomas DJ, Atwell WA (1995) Starches. Eagan Press, Saint Paul

3. Shanefield DJ (1999) Organic additives and ceramic processing. Kluwer Academic Publishers, Berlin

4. Gregorova E, Pabst W (2007) Porosity and pore size control in starch consolidation casting of oxide ceramics-achievements and problems. J Eur Ceram Soc 27:669-672

5. Banks W, Greenwood CT (1975) Starch and its components. Aberdeen University Press, Aberdeen

6. Van Beynum GMA, Roels JA (1985) Starch conversion technology. Marcel Dekker Inc., New York

7. Sayaslan A, Chung OK, Seib PA, Seitz LM (2000) Volatile compounds in five starches. Cereal Chem 77:248-253

8. Whistler RL, BeMiller JN, Paschall EF (1984) Starch: chemistry and technology. Academic Press, Orlando

9. Tomasik P, Pałasiński M, Wiejak S (1989) The thermal decomposition of carbohydrates. Part I. The decomposition of mono- diand oligo-saccharides. Adv Carbohydr Chem Biochem 47: 203-278

10. Tomasik P, Pałasiński M, Wiejak S (1989) The thermal decomposition of carbohydrates. Part II. Starch. Adv Carbohydr Chem Biochem 47:279-344

11. Radley JA (1976) Starch production technology. Applied Science Publishers Ltd, London

12. Radley JA (1968) Starch and its derivatives. Chapman and Hall, London

13. Ball S, Guan H-P, James M, Myers A, Keeling P, Mouille G, Buleon A, Colonna P, Preiss J (1996) From glycogen to amylopectin: a model for the biosynthesis of the plant starch granule. Cell 86:349-352

14. Petersen NB (1975) Edible starches and starch-derived syrups. Neyes Data Corporation, Park Ridges

15. Tomasik P, Schilling CH (1998) Starch complexes. Part I. Complexes with inorganic guests. Adv Carbohydr Chem Biochem 53:263-343

16. Kearsley MW, Dziedzic SZ (1995) Handbook of starch hydrolysis products and their derivatives. Blackie Academic \& Professional, Glasgow

17. Szymońska J, Wodnicka K (2005) Effect of multiple freezing and thawing on the surface and functional properties of granular potato starch. Food Hydrocoll 19:753-760

18. Sikora M, Izak P (2006) Starch and its derivatives in the ceramic processing. Polski Biuletyn Ceramiczny, Krakow

19. Zak AK, Majid WHA, Mahmoudian MR, Darroudi M, Yousefi R (2013) Starch-stabilized synthesis of $\mathrm{ZnO}$ nanopowders at low temperature and optical properties study. Adv Powder Technol 24:618-624

20. Balcha A, Yadav OP, Dey T (2016) Photocatalytic degradation of methylene blue dye by zinc oxide nanoparticles obtained from precipitation and sol-gel methods. Environ Sci Pollut Res 23:25485-25493

21. de Almeida WL, Rodembusch FS, Ferreira NS, de Sousa VC (2020) Eco-friendly and cost-effective synthesis of $\mathrm{ZnO}$ nanopowders by Tapioca assisted sol-gel route. Ceram Int 46: 10835-10842

22. Darroudi M, Sarani M, Oskuee RK, Zak AK, Hosseini HA, Gholami L (2014) Green synthesis and evaluation of metabolic activity of starch mediated nanoceria. Ceram Int 40:2041-2045

23. Ferreira NS, Angelica RS, Marques VB, de Lima CCO, Silva MS (2016) Cassava-starch-assisted sol-gel synthesis of $\mathrm{CeO}_{2}$ nanoparticles. Mater Lett 165:139-142
24. Alishah H, Pourseyedi S, Ebrahimipour SY, Mahani SE, Rafiei N (2017) Green synthesis of starch-mediated $\mathrm{CuO}$ nanoparticles: preparation, characterization, antimicrobial activities and in vitro MTT assay against MCF-7 cell line. Rend Lincei 28:65-71

25. Khodadadi B (2016) Facile sol-gel synthesis of Nd, Ce-codoped $\mathrm{TiO}_{2}$ nanoparticle using starch as a green modifier: structural, optical and photocatalytic behaviors. J Sol-Gel Sci Tech 80:793-801

26. Zhang X, Li P, Guo Y, Yang X, Yan T, Guo X, Li F (2016) Preparation of alumina ultrafine powders through acrylamide, starch and glutaric dialdehyde mediated sol-gel method. Ceram Int 42:6587-6594

27. Koferstein R, Hesse D, Ebbinghaus SG (2011) Synthesis and characterization of a nano-scaled barium cerate perovskite powder using starch as polymerization agent. Solid State Ion 203:52-56

28. Koferstein R, Ebbinghaus SG (2013) Synthesis and characterization of nano- $\mathrm{LaFeO}_{3}$ powders by a soft-chemistry methodand corresponding ceramics. Solid State Ion 231:43-48

29. Koferstein R, Jager L, Ebbinghaus SG (2013) Magnetic and optical investigations on $\mathrm{LaFeO}_{3}$ powders with different particle sizes and corresponding ceramics. Solid State Ion 249-250:1-5

30. Tizro AT, Kamali M (2016) Synthesis of Ag-doped PbTiO3 nanoparticles: feasibility study of its decolorization of simulated methyl orange dye wastewater. Mater Electron 27:8613-8618

31. Ge CC, Rogachev AS (2001) Self-propagating high-temperature synthesis. Trans Tech Publications Ltd, Baech

32. Tahmasebi K, Paydar MH (2008) The effect of starch addition on solution combustion synthesis of $\mathrm{Al}_{2} \mathrm{O}_{3}-\mathrm{ZrO}_{2}$ nanocomposite powder using urea as fuel. Mater Chem Phys 109:156-163

33. Bai J, Liu J, Li C, Li G, Du Q (2011) Mixture of fuels approach for solution combustion synthesis of nanoscale $\mathrm{MgAl}_{2} \mathrm{O}_{4}$ powders. Adv Powder Technol 22:72-76

34. Qui M, Du X, Wang J, Humail IS, Qu X (2009) Influence of carbon on the synthesis of AlN powder from combustion synthesis precursors. J Eur Ceram Soc 29:795-799

35. Bai J, Wei C, Zhao Y, Tan H, Liu J (2011) Solution combustion synthesis and characteristics of nanoscale $\mathrm{MgO}$ powders. Ceram Silik 55:20-25

36. Raja G, Saranya R, Saravanan K (2018) Microwave combustion method: rffect of starch, urea and glycine as processing fuels in the $\mathrm{Co}_{3} \mathrm{O}_{4}$ nanostructures. Optik 153:73-80

37. Visinescu D, Jurca B, Ianculescu A, Carp O (2011) Starch-a suitable fuel in new low-temperature combustion-based synthesis of zinc aluminate oxides. Polyhedron 30:2824-2831

38. Koferstein R (2014) Synthesis, phase evolution and properties of phase-pure nanocrystalline $\mathrm{BiFeO}_{3}$ prepared by a starch-based combustion method. J Alloy Compd 590:324-330

39. Khattab RM, Sadek HEH, Gaber AA (2017) Synthesis of $\mathrm{Co}_{\mathrm{x}} \mathrm{Mg}_{1-\mathrm{x}}$ $\mathrm{Al}_{2} \mathrm{O}_{4}$ nanospinel pigments by microwave combustion method. Ceram Int 43:234-243

40. Koferstein R, Walther T, Hesse D, Ebbinghaus SG (2013) Preparation and characterization of nanosized magnesium ferrite powders by a starch-gel process and corresponding ceramics. J Mater Sci 48:6509-6518

41. Yadav RS, Havlica J, Masilko J, Kalina L, Wasserbauer J, Hajduchova M, Enev V, Kuritka I, Kozakova Z (2015) Effects of annealing temperature variation on the evolution of structural and magnetic properties of $\mathrm{NiFe}_{2} \mathrm{O}_{4}$ nanoparticles synthesized by starch-assisted sol-gel auto-combustion method. J Magn Magn Mater 394:439-447

42. Yadav RS, Havlica J, Hnatko M, Sajgalik P, Alexander C, Palou M, Bartnickova E, Bohac M, Frajkorova F, Masilko J, Zmrzly M, Kalina L, Hajduchova M, Enev V (2015) Magnetic properties of $\mathrm{Co}_{1-\mathrm{x}} \mathrm{Zn}_{\mathrm{x}} \mathrm{Fe}_{2} \mathrm{O}_{4}$ spinel ferrite nanoparticles synthesized by starchassisted sol-gel autocombustion method and its ball milling. $\mathrm{J}$ Magn Magn Mater 378:190-199 
43. Yadav RS, Havlica J, Masilko J, Kalina L, Wasserbauer J, Hajduchova M, Enev V, Kuritka I, Kozakova Z (2016) Impact of $\mathrm{Nd}^{3+}$ in $\mathrm{CoFe}_{2} \mathrm{O}_{4}$ spinel ferrite nanoparticles on cation distribution, structural and magnetic properties. J Magn Magn Mater 399:109-117

44. Yadav RS, Havlica J, Masilko J, Tkacz J, Kuritka I, Vilcakova J (2016) Anneal-tuned structural, dielectric and electrical properties of $\mathrm{ZnFe}_{2} \mathrm{O}_{4}$ nanoparticles synthesized by starch-assisted sol-gel autocombustion method. J Mater Sci Mater Electron 27:5992-6002

45. Dinh TT, Nguyen TQ, Quan GC, Nguyen VDN, Tran HQ, Le TK (2017) Starch-assisted sol-gel synthesis of magnetic $\mathrm{CuFe}_{2} \mathrm{O}_{4}$ powder as photo-Fenton catalysts in the presence of oxalic acid. Int J Environ Sci Tech 14:2613-2622

46. Ansari F, Sobhani A, Salavati-Niasari M (2018) Simple sol-gel synthesis and characterization of new $\mathrm{CoTiO}_{3} / \mathrm{CoFe}_{2} \mathrm{O}_{4}$ nanocomposite by using liquid glucose, maltose and starch as fuel, capping and reducing agents. J Colloid Interface Sci 514:723-732

47. Smirnova MN, Kop'eva MA, Beresnev EN, Goeva LV, Simonenko NP, Nikiforova GE, Trukhanov AV, Ketsko VA (2018) Synthesis of $\mathrm{Mg}\left(\mathrm{Fe}_{0.8} \mathrm{Ga}_{0.2}\right)_{2} \mathrm{O}_{4}$ by gel combustion using glycine and starch. Russ J Inorg Chem 63:1257-1261

48. Agilandeswari K, Kumar AR (2014) Synthesis, characterization, temperature dependent electrical and magnetic properties of $\mathrm{Ca}_{3} \mathrm{Co}_{4} \mathrm{O}_{9}$ by a starch assisted sol-gel combustion method. $\mathrm{J}$ Magn Magn Mater 364:117-124
49. Freitas BGA, Siqueira Jr JM, da Costa LM, Ferreira GB, Resende JALC (2017) Synthesis and characterization of $\mathrm{LiCoO}_{2}$ from different precursors by sol-gel method. J Brazil Ceram Soc 28:2254-2266

50. Motevalian A, Salem S (2016) Effect of glycine-starch mixing ratio on the structural characteristics of $\mathrm{MgAl}_{2} \mathrm{O}_{4}$ nano-particles synthesized by sol-gel combustion. Particuology 24:108-112

51. Ramasami AK, Naika HR, Nagabhushana H, Ramakrishnappa $T$, Balakrishna GR, Nagaraju G (2015) Tapioca starch: an efficient fuel in gel-combustion synthesis of photocatalytically and antimicrobially active $\mathrm{ZnO}$ nanoparticles. Mater Charact 99:266-276

52. Okano T, Suzuki Y (2016) Hydrothermal synthesis of carbonaceous spheres starting from different starches. J Ceram Soc Jpn 124:79-81

53. Wei G, Qu J, Yu Z, Li Y, Guo Q, Qi T (2015) Mineralizer effects on the synthesis of amorphous chromium hydroxide and chromium oxide green pigment using hydrothermal reduction method. Dyes Pigm 113:487-495

54. Yang Q, Yang J, Yang H, Su W, Ruan J (2016) Synthesis and characterization of WC-Co nanosized composite powders with in situ carbon and gas carbon sources. Met Mater Int 22:663-669

55. Visinescu D, Paraschiv C, Ianculescu A, Jurca B, Vasile B, Carp $O$ (2010) The environmentally benign synthesis of nanosized $\mathrm{Co}_{\mathrm{x}} \mathrm{Zn}_{1-\mathrm{x}} \mathrm{Al}_{2} \mathrm{O}_{4}$ blue pigments. Dyes Pigm 87:125-131 